\title{
The impact of trade openness on environmental quality: an empirical analysis of emerging and developing economies
}

\author{
J. Bernard ${ }^{1} \&$ S. K. Mandal ${ }^{2}$ \\ ${ }^{1}$ Wageningen University, The Netherlands \\ ${ }^{2}$ Indian Institute of Technology Madras, India
}

\begin{abstract}
This study examines the impact of trade openness on environmental quality using a dynamic panel data model for 60 emerging and developing economies. We attempt to examine the trade-environment relationship for the period 2002 to 2012 , employing Environmental Performance Index (EPI) and $\mathrm{CO}_{2}$ emissions as the two indicators of environmental quality. The paper tries to fill in the lack of dynamic panel data models investigating trade-environment relationship in emerging economies. The fixed effects model elicits that trade openness improves EPI, albeit it increases $\mathrm{CO}_{2}$ emissions. When corrected for endogeneity, trade openness was found to have no significant impact on EPI, though it escalates $\mathrm{CO}_{2}$ emissions. GMM findings with EPI highlight that political factors improve environmental quality, whereas income and population have detrimental effects. In the GMM estimations with $\mathrm{CO}_{2}$ emissions, trade openness, income, energy consumption and population were found to have deleterious effects on environmental quality. The empirical findings impart support to the contentions over the impact of trade on environmental quality. Efficacious economic, energy, infrastructural and institutional policies hold the key to environmental sustainability in emerging economies.

Keywords: international trade, environmental performance, carbon emissions, governance, endogeneity.
\end{abstract}

\section{Introduction}

The impact of international trade on the environment has been a subject of intense debates many a times. The waves of globalization which swept through the 
developed and developing countries alike have brought the issues of 'pollution havens' as well as 'race to bottom' to the limelight of environmental economics. Different studies have incorporated different models, several panels of countries, econometric techniques and variables emphasising the multiple linkages between trade and environment. The empirical literature on trade and environment elicits evidences supporting reduction in environmental degradation and the adverse impact of trade on environment, thus rendering the field ridden with mixed results.

There are theoretical models which predict that rise in trade coupled with weaker environmental regulations will lead to an increase in pollution in the Global South. The models emphasise on the comparative advantage that poorer countries have in lax environmental regulations and posit that it would lead to agglomeration of pollution intensive, 'dirty' industries in the poorer countries whereas the richer countries will produce 'cleaner' products. Studies have found evidence for the reduction in environmental degradation in developed countries [1] while nations with lax environmental regulations turning into pollution havens in the developing world [2, 3]. Apart from the pollution haven effect, environmentalists also fear that 'race to bottom' among world nations to upkeep their international competitiveness could exacerbate environmental problems [4]. But empirical evidences have been mainly contradictory and find no 'race to the bottom' [5].

The debates on the impact of trade on environment are pertinent considering the increasing volume of trade among world nations and the changes in environmental quality. In 2002, the average trade as a percentage of GDP across the selected 60 emerging and developing economies (EDEs) was 60.40 . The trade gained momentum during the decade and reached $71.09 \%$ in 2012 [6]. EDEs witnessed substantial inflows of Foreign Direct Investment after the waves of globalization in the 1980s and 1990s. FDI net inflows to these countries as a percentage of GDP which was $28.43 \%$ in 2002 rose over the period of 10 years reaching $37.19 \%$ in 2012 [6]. The impact of economic crisis felt on developed economies led to a reduction in FDI and trade volumes in developing countries, nonetheless it recovered by 2012 .

When trade, economic growth and investment flows underwent considerable surge in the EDEs, it did have an impact on the environmental quality. In spite of concerted international efforts to reduce greenhouse gases in place including the Kyoto Protocol, $\mathrm{CO}_{2}$ emissions per capita (territorial emissions) rose from 4.71 metric tons in 2002 to 5.83 metric tons in 2012 in EDEs. In the same period the aggregate carbon dioxide emissions by the 60 EDEs saw a rise from 6497.2 mega tons in 1990 to 11101.29 mega tons in 2000 and reached a whopping 18792.79 mega tons in 2010 [7]. It is in this context this research examines the impact of trade on environmental quality in a multivariate framework, to get a comprehensive picture of the scenario.

The remainder of the paper is organized as follows. Section 2 discusses the literature, Section 3 highlights the research gap and Section 4 presents data, model and methodology. Section 5 includes the estimation results and discussions while Section 6 concludes the study. 


\section{Literature review}

The literature on the relationship between trade and environment can be distinguished into two broad categories on the basis of the objectives of the works. There are works which emphasise on the causality analysis of the variables and others which examine the impact of trade on the environment. This study follows the second strand and tries to find evidence for the impact of trade on environmental quality in developing and emerging economies for 2002-2012 period. Nevertheless, the paper attempts to include theoretical and empirical explanations behind both categories of studies in the literature review and takes up the latter category exclusively in the empirical analysis.

Existing studies on the relationship between trade and environment give evidences for positive, negative and ambiguous effects. The course of research explaining the impact of income on environment mainly follows the path of Environmental Kuznets Curve analysis. EKC analyses have found an increase in pollution with income for certain pollutants and reduction for several others. There are studies which found evidence for inverted U-shaped EKC, the N-shaped curve and a monotonically increasing curve [8-10]. However, we do not investigate evidence for $\mathrm{EKC}$, though we include economic growth as a determinant of environmental quality.

When several studies found beneficial impact of trade of environment, others either found the adverse impact of trade or no impact at all. The seminal work in the field, by Grossman and Krueger [11], studied the impact of NAFTA on Mexico and found out that it was the relative factor endowments which determined the pattern of trade in the case of US and Mexico concluding that trade was good for Mexico. The literature which followed this pioneering work can be distinguished on the basis of the findings. There is one strand of literature which posits that increasing trade can improve competitiveness and bring in advanced technologies to developing countries, thus making trade beneficial for all [8]. Another strand of literature highlighted the deleterious effects of trade via increasing emissions and depletion of resources $[12,13]$. Many works also ventured into finding evidences for Pollution Haven Hypothesis (PHH) and Race to Bottom. Birdsall and Wheeler [14] which looked for evidence of PHH in Latin American countries finds out that the rise in pollution intensity in the developing countries coincided with the stringent regulations adopted by OECD. Mani and Wheeler [15] looks for evidences for pollution havens through cross country analysis and finds evidence for PHH but posits that the pollution havens are 'self-limiting' and only 'transient' like the low-wage havens. However, evidence supporting race to bottom was hardly found [5].

Addressing endogeneity which was overlooked by several studies in the 1990s was a priority of many later studies. In this context, Frankel and Rose [5] particularly looked at the effect of trade on environment using cross-country data and found evidence for positive effect of trade in the case of certain pollutants like $\mathrm{SO}_{2}$. Cole et al. [16] looked into the relationship between economic growth, FDI and environment in the context of China. The paper finds EKC relationship for waste water and petroleum like matter and finds out that foreign owned firms have 
detrimental influence on emissions though not as strong as domestic firms. Sharma [17] studied the determinants of carbon dioxide emissions in the context of 69 countries using a dynamic panel data model. The paper found no significant impact of trade openness on the environment in the global panel, though it found that urbanization reduces $\mathrm{CO}_{2}$ emissions while GDP increases it. Omri et al. [18] investigates the relationship between financial development, $\mathrm{CO}_{2}$ emissions, trade and economic growth for 12 MENA countries. They find evidence for bidirectional causality between $\mathrm{CO}_{2}$ emissions and economic growth and verify EKC.

\section{Research gap}

The initial studies which examined the relationship between trade and environment were plagued by unobserved heterogeneity and endogeneity. The estimations with cross sectional data also restricted the scope of those studies. Most of the studies in the 1990s thus gave insignificant results and small magnitudes while examining the trade-environment relation. The introduction of Instrumental Variable methods to correct for endogeneity and the use of gravity models were on a rise since the work of Frankel and Rose [5]. Panel data studies mostly used environmental quality/emissions equation where pollution measures are regressed on measures of trade openness.

However, the literature on trade-environment nexus is ridden with mixed results. Different dependent variables are used by different studies and this could lead to the rise in mixed results. The studies which use local pollutants as the indicator vary from the ones which use global pollutant like $\mathrm{CO}_{2}$ in terms of the findings, as the two affect the environment differently. Another source of varied results is the use of concentrations data or emissions data. Since emission data is constructed unlike the directly observed concentration data, the method of construction can lead to different results in estimations. An ideal way to tackle this would be to include estimations with indices or indicators like an emissions or sustainability indicator which capture the overall impact of trade or economic growth on the environment. There could also be differences in the results among studies as they use different pollutants. The differences are highly pronounced in the case of local vs global pollutant based estimations.

Factor endowments and environmental regulations simultaneously determine the composition effect in trade. Korves et al. [19] opines that cancelling out of the two influences may render the attempts to find evidence for PHH to be futile. Another important factor causing the differences in result is the aggregation of data. Aggregate analysis could overshadow the individual industry specific effects thus leading to erroneous results. In addition to the aggregation problem, unobserved heterogeneity can result in misleading results. Inclusion of country specific and industry specific factors in the model can save the model from misspecification. Endogeneity too can lead to erroneous results if it is not taken care in the model. Most of the recent works have taken this into consideration and there are only a few studies in isolation which suffer from endogeneity. 


\section{Model and methodology}

\subsection{Model}

This study follows the literature on impact of trade openness on the environmental quality and focuses on a panel data approach. The empirical specification used in the work derives from the standard trade-environment framework with additional variables of FDI, Financial Development, Urbanization and Political Globalization. As OLS could lead to biased results in the presence of unobserved heterogeneity, we employ random effects or fixed effects to obtain better results. Fixed effects model treats the individual specific time constant factors as regression parameters, while the random effects model treats them as components of the random disturbance. Hausman test was conducted and Fixed Effects model was found to fit the case here. There could be large heterogeneity due to the wide variations among nations in income, trade and environmental variables. Keeping in view endogeneity as well, we employ a dynamic panel data model following the Blundell-Bond system GMM estimation. Dynamic panel data GMM estimation overcomes the problem of endogeneity which could not be solved by panel data models based on Fixed and Random Effects. We employ the two-step variant of GMM estimation which uses the corrected standard errors [20] thus rendering the two step system GMM estimates more robust than one-step estimates. GMM estimation takes into account the dynamic nature of our model which has been incorporated previously by Tamazian and Rao [21] and Sharma [17]. It has been highlighted in the literature that GMM accommodates for the dynamic nature of the system and takes care of endogeneity in the model [21, 22]. GMM estimation can also evade the bias arising while including lagged dependent variables as regressors [17].

\subsection{Data and methodology}

The paper studies 60 EDEs from Asia, Latin America, Europe and Africa. We followed the IMF classification 2014 of emerging and developing economies and selected the 60 countries excluding the low income developing countries due to unavailability of data. The availability of back casted EPI data with 2014 specification has restricted our study to the time period 2002-2012. To the knowledge of the authors, the current study which incorporates data for the EDEs and a comprehensive Environment Index following a dynamic panel data model is the first of its nature. The data has been collected from the UNCTAD, US Energy Information Administration (EIA), World Governance Indicators, KOF Index of Globalization and World Bank World Development Indicators. The 2014 Environmental Performance Index is a joint project between the Yale Centre for Environmental Law and Policy (YCELP) and the Centre for International Earth Science Information Network (CIESIN) at Columbia University. The Environmental Performance Index (EPI) is constructed incorporating the calculation and aggregation of 20 indicators which replicate the national level environmental performance giving them appropriate weights. Carbon dioxide 
emissions have been considered as the indicator for environmental factor in the second equation. Data on $\mathrm{CO}_{2}$ emissions per capita are from World Bank WDI and Global Carbon Budget 2013.

GDP, Trade Openness, Energy Consumption, Financial Development, FDI, Urbanization, Political Globalization and Governance are the explanatory variables in the multivariate analysis. The course of research explaining the impact of income on environment mainly follows the path of Environmental Kuznets Curve analysis. EKC analyses have found increase in pollution with income for certain pollutants and reduction for several others [8-10]. Trade Openness is measured as the sum of exports and imports as a percentage of GDP. Trade Openness can impact EPI through the scale, technique and composition effects as have been explicated in the literature survey. The paper includes Primary Energy Consumption per capita data obtained from US Energy Information Administration (EIA). Energy Consumption can increase carbon emissions and affect the EPI through the rise in emissions, as well as improve living conditions. This has been considered based on findings on impact of energy consumption on environment through trade and economic growth [23, 24]. We have included FDI as the percentage of net FDI inflows to GDP and financial development as Domestic credit to private sector as a percentage of GDP. FDI can indeed affect the economic growth which can further impact the environmental performance or emissions in an economy. It can be the facilitator for the technique effect via improved, eco-friendly technologies for the production processes [24, 25]. Financial development acts as a channel which can attract FDI to an economy that affects environmental performance through economic growth [26]. Moreover, Financial Development can provide opportunity to use advanced, environment friendly technologies for production [21].

The study has incorporated Governance and other socio economic factors affecting environmental quality. Significance of political freedom and democratic set up of country in determining the response to sustainability has been explicated in literature [27-29]. Tamazian and Rao [21] includes a variable to capture institutional quality or efficiency and Chakraborty and Mukherjee [30] has Hybrid HDI, Corruption Perceptions Index and Democracy Index score to study impact of trade on environment. We incorporate a Government Effectiveness Score from the Worldwide Governance Indicators. For taking into account the nations' efforts in the global front towards environment, we have included political globalization score from KOF Globalization Index. The political globalization score is constructed on the basis of International treaties signed by the nation, participation in UN Security Council Missions etc. Urbanization is an explanatory variable which is measured as the percentage of urban population in the economy. Urbanization can increase carbon emissions or reduce EPI as it promotes economic growth; on the other hand can improve environmental quality by attaining economies of scale through improved infrastructure [31]. As control variables, the study includes the total population in the country and inflation. Inflation indicates macro-economic stability [21] which can ensure better sustainability in an economy. 
The following regression models are incorporated to study the relationship between trade openness and environmental quality. Eq. (1) is with fixed effects and eq. (2) is with GMM estimations.

$$
\begin{aligned}
\text { LnEPI }_{i t}=\alpha_{1}+ & \alpha_{2} \text { LnTradeopenness }_{i t}+\alpha_{3} \text { LnFDI }_{i t}+\alpha_{4} \text { LnGDP }_{i t} \\
& +\alpha_{5} \text { LnFinancial Development }_{i t} \\
& +\alpha_{6} \text { LnUrbanization }_{i t}+\alpha_{7} \text { LnGovernance }_{i t} \\
& +\alpha_{8} \text { LnPolitical Globalization }_{i t} \\
& +\alpha_{9} \text { Ln Energy Consumption }_{i t} \\
& +\alpha_{10} \text { LnInflation }_{i t}+\alpha_{11} \text { LnPopulation }_{i t}+u_{i} \\
& +v_{i t} \\
& \\
\text { LnEP } & \text { Iit }=\gamma_{0}+\gamma_{1} \text { Ln EPI }_{i t-1}+\gamma_{2} \text { LnEPI }_{i t-2} \\
& +\gamma_{3} \text { LnTradeopenness }_{i t}+\gamma_{4} \text { LnFDI I }_{i t} \\
& +\gamma_{5} \text { LnGDP }_{\text {it }}+\gamma_{6} \text { LnFinancial development }_{i t} \\
& +\gamma_{7} \text { LnUrbanization }_{i t}+\gamma_{8} \text { LnGovernance }_{i t} \\
& +\gamma_{9} \text { LnPoliticalGlobalization }_{i t} \\
& +\gamma_{10} \text { LnEnergyconsumption }_{i t} \\
& +\gamma_{11} \text { LnInflation }_{\text {it }}+\gamma_{12} \text { LnPopulation }_{i t}+u i \\
& +v_{i t}
\end{aligned}
$$

We also include estimations with carbon dioxide emissions as the dependent variable. Keeping in view that panel data reduces collinearity among the explanatory variables, increases the degrees of freedom and gives more variability and efficiency [32], we estimate the equation in fixed effect model in the first stage and proceeds with the GMM estimation in the next stage. We incorporate Blundell and Bond [32] GMM estimator which improves upon the Arellano and Bond [33] estimator by including lagged levels as well as lagged differences as instruments. We have presented only GMM estimation results in the tables.

\section{Results and discussions}

The fixed effects model indicates that the EPI increases with economic growth and trade openness confirming Chakraborty and Mukherjee [30]. Both GDP and trade openness are found to have significant positive impact on EPI. For regressions with $\mathrm{CO}_{2}$ emissions as the dependent variable, we found that economic growth and trade openness increases $\mathrm{CO}_{2}$ emissions. The GMM estimations following Blundell and Bond [32] estimation procedure are reported in tables 1 and 2. To check for the validity of over-identifying restrictions, Hansen's test statistics have been reported. The standard errors are corrected for heteroscedasticity, tests for serial correlations were conducted as well and the results are reported.

The GMM estimation results have significant results like the fixed effects models for most variables but not for trade openness. However, in this GMM estimation it was found that per capita income is negatively related with environmental quality, i.e. as GDP rises, EPI is falling. This confirms the results of Dasgupta et al. [34], Tamazian and Rao [21], Arouri et al. [35] and Omri et al. 
Table 1: $\quad$ GMM estimations with EPI.

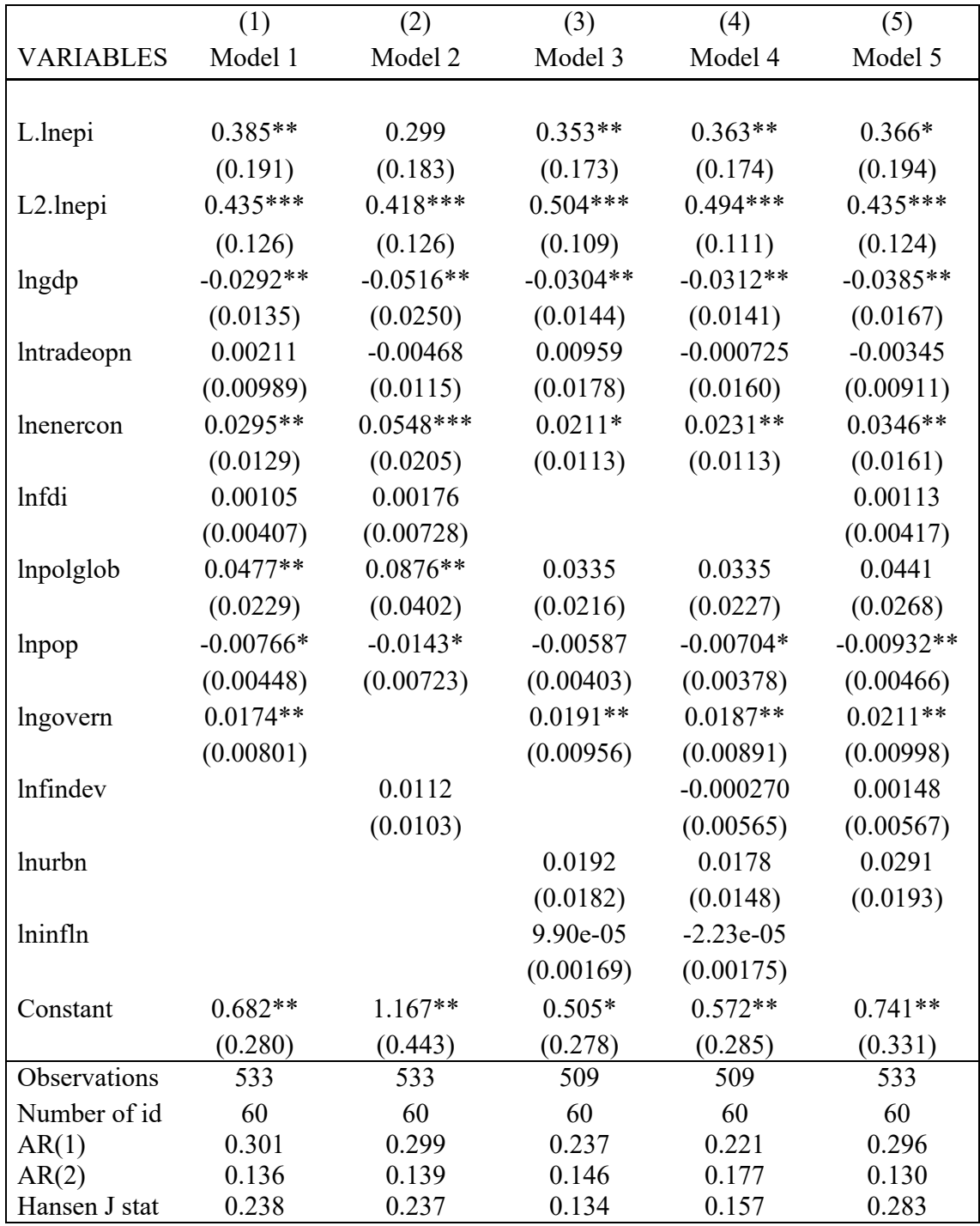

Robust standard errors in parentheses

$* * * \mathrm{p}<0.01, * * \mathrm{p}<0.05, * \mathrm{p}<0.1$

[18] though it contradicts Chakraborty and Mukherjee [30]. This effect arose when we solved for both heterogeneity and endogeneity by employing GMM estimation thus demonstrating that economic growth reduces environmental sustainability. Government Effectiveness is found to have a positive impact on EPI which was an expected result since better political and social conditions are conducive to environmental sustainability in an economy. This confirms the findings of 
Morrison [29] and Chakraborty and Mukherjee [30]. Highlighting the relevance of international efforts for ensuring environmental sustainability, political globalization is found to have a positive impact on EPI. Urbanization was found to have an insignificant impact on EPI. Urbanization improves infrastructure which contribute to the health benefits, water and sanitation components of EPI thus cancelling out the negative effects via economic growth on ecosystem vitality and is in the lines of Sadorsky [31]. FDI was found to be insignificant and this renders the technique effect towards environmental quality to be negligible.

Energy consumption is found to improve EPI. In the case of energy consumption, the positive effect via contributing to health effects would have been higher than the negative effects via increased emissions. Higher energy consumption also points towards better standards of living which call for effective actions to achieve sustainability. Our result of energy consumption improving EPI contradicts the findings of Tamazian and Rao [21], Hossain [36] and Omri et al. [18] which find that use of energy increases environmental degradation. We believe that the contradiction arises as these studies use $\mathrm{CO}_{2}$ emissions as the environmental indicator, and EPI in our study being a comprehensive index, accounts for positive effects of increased energy use through improved health, water and sanitation facilities.

The study also includes GMM estimation with carbon dioxide emissions as the dependent variable. This model has been reported in table 2. Per capita income has a positive impact on $\mathrm{CO}_{2}$ emissions and the results are consistent with the findings in Arouri et al. [35] and Omri et al. [18]. The increase in scale of activities in an economy with rise in income leads to rising $\mathrm{CO}_{2}$ levels. Moreover, it has been found that trade openness has a significant positive impact on $\mathrm{CO}_{2}$ emissions in models 3 and 5. This confirms the results by Tamazian and Rao [21] and Omri et al. [18] for a section of countries they studied. The positive and significant impact of trade openness on $\mathrm{CO}_{2}$ emissions confirms the findings of Managi et al. [3] and Omri et al. [18]. The results in model 6 indicate that $1 \%$ rise in trade openness increases $\mathrm{CO}_{2}$ emissions by $0.21 \%$. This provides evidence for the developing and emerging economies becoming Pollution Havens with greater volumes of trade.

Energy consumption has a positive impact on $\mathrm{CO}_{2}$ emissions in all the models. This confirms the findings of Arouri et al. [35]. Higher energy consumption which occurs as a result of higher economic growth can lead to greater $\mathrm{CO}_{2}$ emissions. Population is also found to have a positive impact on the $\mathrm{CO}_{2}$ emissions which has been found earlier by Shi [37]. Unlike the fixed effects model, political globalization is found significant when endogeneity has been controlled for. Models 1, 2 and 4 posit that political globalization brings down carbon dioxide emissions which imposes controls on the $\mathrm{CO}_{2}$ emissions. This emphasises the role of joint international efforts in combating global climate threats like greenhouse gas emissions.

There are differences among the results reported depending on the dependent variable. EPI being a comprehensive index considers the overall impact of the factors on environment whereas, $\mathrm{CO}_{2}$ emissions consider only the impact of explanatory variables on emissions of a global pollutant. The differences in results 
Table 2: $\quad$ GMM estimations with $\mathrm{CO}_{2}$ emissions.

\begin{tabular}{|c|c|c|c|c|c|}
\hline VARIABLES & $\begin{array}{l}\text { (1) } \\
\text { Model 1 } \\
\end{array}$ & $\begin{array}{l}\text { (2) } \\
\text { Model } 2 \\
\end{array}$ & $\begin{array}{l}\text { (3) } \\
\text { Model } 3 \\
\end{array}$ & $\begin{array}{l}\text { (4) } \\
\text { Model } 4 \\
\end{array}$ & $\begin{array}{l}\mathbf{5}) \\
\text { Model } 5\end{array}$ \\
\hline L.Inco2 & $\begin{array}{l}0.345^{*} \\
(0.184)\end{array}$ & $\begin{array}{l}0.327 * \\
(0.185)\end{array}$ & $\begin{array}{l}0.454 * * \\
(0.217)\end{array}$ & $\begin{array}{l}0.229 \\
(0.160)\end{array}$ & $\begin{array}{l}0.413 * \\
(0.235)\end{array}$ \\
\hline L2.lnco 2 & $\begin{array}{l}0.0646^{*} \\
(0.0369)\end{array}$ & $\begin{array}{l}0.043 \\
(0.036)\end{array}$ & $\begin{array}{l}0.0319 \\
(0.0540)\end{array}$ & $\begin{array}{l}0.0624 * * \\
(0.0251)\end{array}$ & $\begin{array}{l}-0.00902 \\
(0.0588)\end{array}$ \\
\hline $\operatorname{lngdp}$ & $\begin{array}{l}0.250^{*} \\
(0.145)\end{array}$ & $\begin{array}{l}0.298^{* *} \\
(0.141)\end{array}$ & $\begin{array}{l}-0.0302 \\
(0.0683)\end{array}$ & $\begin{array}{l}0.255^{*} \\
(0.133)\end{array}$ & $\begin{array}{l}0.167 \\
(0.221)\end{array}$ \\
\hline Intradeopn & $\begin{array}{l}-0.0728 \\
(0.137)\end{array}$ & $\begin{array}{l}-0.073 \\
(0.138)\end{array}$ & $\begin{array}{l}0.178^{*} \\
(0.0896)\end{array}$ & $\begin{array}{l}-0.115 \\
(0.122)\end{array}$ & $\begin{array}{l}0.209 * * \\
(0.0952)\end{array}$ \\
\hline lnenercon & $\begin{array}{l}0.412 * * \\
(0.165)\end{array}$ & $\begin{array}{l}0.457^{* *} \\
(0.179)\end{array}$ & $\begin{array}{l}0.510 * * \\
(0.253)\end{array}$ & $\begin{array}{l}0.544 * * * \\
(0.135)\end{array}$ & $\begin{array}{l}0.567 * * \\
(0.268)\end{array}$ \\
\hline lnpop & $\begin{array}{l}0.0798 * * \\
(0.0339)\end{array}$ & $\begin{array}{l}0.082 * * \\
(0.033)\end{array}$ & $\begin{array}{l}0.0567 \\
(0.0348)\end{array}$ & $\begin{array}{l}0.0875 * * * \\
(0.0329)\end{array}$ & $\begin{array}{l}0.0836 \\
(0.0525)\end{array}$ \\
\hline lninfln & $\begin{array}{l}0.0241 \\
(0.0154)\end{array}$ & $\begin{array}{l}0.025^{*} \\
(0.015)\end{array}$ & & $\begin{array}{l}0.0130 \\
(0.0138)\end{array}$ & \\
\hline lnpolglob & $\begin{array}{l}-0.294 * \\
(0.152)\end{array}$ & $\begin{array}{l}-0.283^{*} \\
(0.153)\end{array}$ & & $\begin{array}{l}-0.282^{*} \\
(0.151)\end{array}$ & \\
\hline lngovern & & & $\begin{array}{l}-0.0313 \\
(0.0415)\end{array}$ & $\begin{array}{l}-0.0862 \\
(0.0535)\end{array}$ & $\begin{array}{l}-0.0765 \\
(0.0699)\end{array}$ \\
\hline $\operatorname{lnfdi}$ & & & $\begin{array}{l}0.000310 \\
(0.0327)\end{array}$ & & $\begin{array}{l}0.00533 \\
(0.0450)\end{array}$ \\
\hline lnurbn & & $\begin{array}{l}-0.279 \\
(0.182)\end{array}$ & & & $\begin{array}{l}-0.544 \\
(0.631)\end{array}$ \\
\hline lnfindev & & & & & $\begin{array}{l}-0.0371 \\
(0.0784)\end{array}$ \\
\hline Constant & $\begin{array}{l}-2.862 * * * \\
(0.997)\end{array}$ & $\begin{array}{l}-2.341 * * \\
(0.952)\end{array}$ & $\begin{array}{l}-2.751 * \\
(1.572)\end{array}$ & $\begin{array}{l}-2.966^{* *} \\
(0.984)\end{array}$ & $\begin{array}{l}-2.591^{*} \\
(1.421)\end{array}$ \\
\hline Observations & 509 & 509 & 533 & 509 & 533 \\
\hline Number of id & 60 & 60 & 60 & 60 & 60 \\
\hline $\mathrm{AR}(1)$ & 0.016 & 0.009 & 0.288 & 0.021 & 0.292 \\
\hline $\operatorname{AR}(2)$ & 0187 & 0.264 & 0.696 & 0.170 & 0.580 \\
\hline Hansen $\mathrm{J}$ stat & 0.117 & 0.100 & 0.389 & 0.195 & 0.394 \\
\hline
\end{tabular}

Robust standard errors in parentheses

$* * * \mathrm{p}<0.01, * * \mathrm{p}<0.05, * \mathrm{p}<0.1$

are also seen with respect to the estimation techniques used. However, the results based on GMM estimations would be more reliable as it takes into account heterogeneity and endogeneity. Our results underline how differences in pollutants and estimation techniques can render varied results while assessing impact of trade openness on environmental quality in a multivariate framework. 


\section{Conclusion and policy implications}

The main objective of the study was to elicit the impact of trade openness on the environment in a multivariate framework. In addition to trade openness, we also examined the impact of investment, governance and financial factors on environmental degradation. We have employed different panel data econometric techniques which include Fixed Effects model to account for country specific unobserved heterogeneity and GMM estimations to tackle endogeneity as well as heterogeneity. The results obtained vary with the techniques employed and this confirms the observation of Stern [38] and Tamazian and Rao [21].

The estimation results with EPI as the environmental indicator demonstrate that environmental quality declines as the income rises, when controlled for endogeneity. This may be due to the detrimental impact of income on ecosystem vitality in EDEs, before scale, composition and technique effects kick in. The estimations with $\mathrm{CO}_{2}$ emissions underscore the results by reporting that income growth increases carbon dioxide emissions. However, trade openness was found to have no significant impact on EPI score when controlled for endogeneity. On the other hand, trade openness was found to have significant positive impact on carbon dioxide emissions. The insignificant impact on EPI can be attributed to the cancelling out of positive effects of trade openness on certain environmental health components against the negative effects on components of ecosystem vitality.

The paper finds that governance and political globalization improves EPI when endogeneity has been controlled. This calls for effective governance initiatives at the national and international levels by the governments of the developing and emerging economies so as to ensure environmental quality coupled with growth. In the GMM estimations with carbon dioxide emissions, population and energy consumption are found to increase the emissions. The findings emphasise the need to have effectual and gradual shift to renewable energy sources which have lower carbon emissions as well as measures to improve efficiency of existing energy production and distribution processes. The positive impact of urbanization on EPI emphasizes the contribution of better infrastructure facilities to overall environmental quality.

The message to the policy makers mainly rests on the impacts of trade, economic growth, FDI, financial development, urbanization, political globalization and governance on environmental quality. The results highlight how trade openness has a detrimental effect on environment through carbon dioxide emissions. This alongside the positive impact of governance calls for effective regulations and legislations to realise green growth. As the developing and emerging economies are on a transition path towards development, the measures taken by them would play a major role in ensuring the safety of the planet. On the whole the results call for comprehensive economic, financial, institutional, and energy policies for guaranteeing environmental sustainability. 


\section{References}

[1] Antweiler W., Copeland B. R. \& Taylor S. M., Is Free trade good for the environment. American Economic Review, 91, pp. 877-908, 2001.

[2] Dinda, S., Globalization and environment: Can pollution haven hypothesis alone explain the impact of globalization on environment? MPRA Paper, 50590, 2006.

[3] Managi, S., Hibiki, A., \& Tsurumi, T., Does trade openness improve environmental quality? Journal of Environmental Economics and Management, 58, pp. 346-363, 2009.

[4] Wheeler, D., Racing to the Bottom? Foreign Investment and Air Pollution in Developing Countries. Journal of Environment and Development, 10, pp. 225-245, 2001.

[5] Frankel, J. \& Rose, A., Is trade good or bad for the environment? Sorting out the causality. Review of Economics and Statistics, 87 (1), pp. 85-91, 2005.

[6] World Bank., Data retrieved February 5, 2015, from World Development Indicators Online (WDI) database, 2015.

[7] Le Quéré, C. et al., Global carbon budget 2013, Earth Systems Science Data, 6, pp. 235-263, doi:10.5194/essd-6-235-2014, 2013.

[8] Copeland, B. R., \& Taylor, M. S., Trade, growth and the environment. Journal of Economic Literature, 42, pp. 7-71, 2004.

[9] Dasgupta, P., Laplantem B., Wang H., \& Wheeler D., Confronting the environmental Kuznets curve. Journal of Economic Perspectives, 16(1), pp. 147-168, 2002.

[10] Dinda, S., Environmental Kuznets curve hypothesis: A survey. Ecological Economics, 49, pp. 431-455, 2004.

[11] Grossman, G.M., \& Krueger, A.B., Environmental impacts of a North American free trade agreement. The US-Mexico Free Trade Agreement (Peter .M. Garber, ed. pp. 13-56). Cambridge, Massachusetts: MIT Press, 1993.

[12] Shahbaz, M., Hye, Q.M.A., Tiwari, A.K., \& Leitao, N.C., Economic growth, energy consumption, financial development, international trade and $\mathrm{CO}_{2}$ emissions in Indonesia. Renewable and Sustainable Energy Reviews, 25, pp. 109-121, 2013c.

[13] Chang, N., The empirical relationship between openness and environmental pollution in China. Journal of Environmental Planning and Management, 55(6), pp. 783-796, 2012.

[14] Birdsall, N. \& Wheeler D., Trade policy and industrial pollution in Latin America: Where are the pollution havens?. Journal of Environment \& Development, 2(1), pp. 137-149, 1993.

[15] Mani, M., \& Wheeler D., In search of pollution havens? Dirty industries in the world economy, 1960 to 1995 . Journal of Environment \& Development, 7(3), pp. 215-247, 1998. 
[16] Cole, M.A., Elliot, R.J.R. \& Zhang, J., Growth, foreign direct investment and the environment: evidence from Chinese cities. Journal of Regional Science, 51 (1), pp. 121-138, 2011.

[17] Sharma, S.S., Determinants of carbon dioxide emissions: empirical evidence from 69 countries. Applied Energy, 88 (1), pp. 376-382, 2011.

[18] Omri, A., Daly, S., Rault, C., \& Chaibi, A., Financial development, environmental quality, trade and economic growth: What causes what in MENA countries. Energy Economics, 48, pp. 242-252, 2015.

[19] Korves N., Martínez-Zarzoso I., \& Voicu A.M., Is free trade good or bad for the environment? New empirical evidence. Climate Change Socioeconomic Effects (Blanco and Kheradmand Eds .pp.1-30). Rijeka, Croatia: InTech, 2011.

[20] Windmeijer, F., A Finite Sample Correction for the Variance of Linear Efficient Two-Step GMM Estimators. Journal of Econometrics, 126, pp. 25-51, 2005.

[21] Tamazian, A., \& Rao, B.B., Do economic, financial and institutional developments matter for environmental degradation? Evidence from transitional economies. Energy Economics, 32(1), pp. 137-145, 2010.

[22] Taguchi, H., The environmental Kuznets curve in Asia: The case of sulphur and carbon emissions. Asia-Pacific Development Journal, 19(2), pp. 77-92, 2012.

[23] Cole, M. A., Does trade liberalization increase energy use? Economics Letters, 92, pp. 108-112, 2006

[24] Ozturk, I., \& Acaravci, A., The long-run and causal analysis of energy, growth, openness and financial development on carbon emissions in Turkey. Energy Economics, 36, pp. 262-267, 2013.

[25] Belloumi, M., The relationship between trade, FDI and economic growth in Tunisia: An application of the autoregressive distributed lag model. Economic Systems, 38, pp. 269-287, 2014.

[26] Frankel, J., \& Romer, D., Does trade cause growth? American Economic Review, 89 (3), pp. 379-399, 1999.

[27] Bernauer, T. \& Koubi, V., On the political determinants of environmental quality. Paper presented at the annual meeting of the American Political Science Association, Hilton Chicago and the Palmer House Hilton, Chicago, IL, 2004.

[28] Fredriksson, P.G., List, J.A., \& Millimet, D.L., Corruption, environmental policy, and FDI: theory and evidence from the United States. Journal of Public Economics, 87, pp. 1407-1430, 2003.

[29] Morrison, A., Democracy and the Environment: The Visibility Factor. Paper Presented at the Annual Meeting of the Midwest Political Science Association 67th Annual National Conference, The Palmer House Hilton, Chicago, I.L., 2 April 2009, 2009.

[30] Chakraborty, D. \& Mukherjee, S., How do trade and investment flows affect environmental sustainability? Evidence from panel data. Environmental Development, 6, pp. 34-47, $2013 \mathrm{a}$. 
[31] Sadorsky, P., The effect of urbanization on $\mathrm{CO}_{2}$ emissions in emerging economies. Energy Economics, 41(C), pp. 147-153, 2014.

[32] Blundell, R. \& Bond, S., Initial conditions and moment restrictions in dynamic panel data models. Journal of Econometrics, 87 (1), pp. 115-143. 1998.

[33] Arellano, M. \& Bond, S.R., Some test of specification for panel data: Monte Carlo evidence and application to employment equations. Review of Economic Studies, 58, pp. 277-297, 1991.

[34] Dasgupta, S., Mody, A., Roy, S., \& Wheeler, D., Environmental regulation and development: A cross-country empirical analysis. World Bank Policy Research Working Paper, vol. 1448. 1995.

[35] Arouri, M. E. H., Youssef, A. B., M'henni H., \& Rault C., Energy Consumption, Economic Growth and CO2 Emissions in Middle East and North African Countries, Discussion Paper Series, IZA DP No. 6412, 2012.

[36] Hossain, M.S., Panel estimation for CO2emissions, energy consumption, economic growth, trade openness and urbanization of newly industrialized countries. Energy Policy, 39, pp. 6991-6999, 2011.

[37] Shi, A., The Impact of Population Pressure on Global Carbon Dioxide Emissions: Evidence from Pooled Cross-Country Data. Ecological Economics, 44, pp. 24-42, 2003.

[38] Stern, D., The rise and fall of the environmental Kuznets curve. World Development, 32 (8), pp. 1419-1439, 2004.

[39] Arellano, M. \& Bover, O., Another look at the instrumental variable estimation of error-component models. Journal of Econometrics, 68, pp. 527, 1995.

[40] Dreher, A., Does Globalization Affect Growth? Evidence from a new Index of Globalization. Applied Economics, 38(10), pp. 1091-1110, 2006.

[41] Kaufmann, D., Kraay, A., \& Mastruzzi, M., The Worldwide Governance Indicators: A Summary of Methodology, Data and Analytical Issues. World Bank Policy Research Working Paper No. 5430, 2010.

[42] UNCTAD., Data retrieved February 10, 2015, from UNCTADstat Online database, 2015.

[43] U.S. Department of Energy, Energy Information Administration., International Energy Outlook 2014, Retrieved from https://www.eia.gov/ forecasts/ieo/, 2014.

[44] WTO., Special Edition on Trade and Environment. Geneva: WTO, 1999. 